\title{
Who Wants Solar Water Heaters and Alternative Fuel Vehicles? Assessing Social- Psychological Predictors of Adoption Intention and Policy Support in China
}

\author{
Chien-fei Chen \\ Research Professor \\ NSF Center for Ultra-wide-area Resilient Electrical Energy Transmission Networks (CURENT) \\ Department of Electrical Engineering and Computer Science \\ The University of Tennessee, Knoxville \\ Xiaojing Xu \\ Post-Doctoral Researcher \\ NSF Center for Ultra-wide-area Resilient Electrical Energy Transmission Networks (CURENT) \\ Department of Electrical Engineering and Computer Science \\ The University of Tennessee, Knoxville \\ and \\ Scott Frey \\ Professor \\ Department of Sociology \\ University of Tennessee
}

This work was supported in part by the Engineering Research Center Program of the National Science Foundation and the Department of Energy under NSF Award Number EEC-1041877 and the CURENT Industry Partnership Program. Correspondence concerning this article should be addressed to Chien-fei Chen, CURENT Engineering Research Center, Department of Electrical Engineering and Computer Science, University of Tennessee, 508 Min H. Kuo Building, 1520 Middle Dr. Knoxville, TN 37996-2250. cchen26@ utk.edu. Phone: 1-865-974-3787; Fax: 1-865974-9723. 


\title{
Who Wants Solar Water Heaters and Alternative Fuel Vehicles? Assessing Social- Psychological Predictors of Adoption Intention and Policy Support in China
}

\begin{abstract}
Renewable energy technologies, such as solar water heaters (SWHs) and alternative fuel vehicles (AFVs), have been widely adopted in China. Using an extended model of the Theory of Planned Behavior, we investigated how social-psychological factors (environmental attitudes, perceived behavioral control [PBC], subjective and descriptive norms, and renewable energy knowledge) affect individuals' intention to adopt SWHs and AFVs and support renewable energy policies for a sample of 655 Chinese university students. Results of structural equation models indicate that environmental attitudes have strong positive effects on the intention to adopt SWHs and AFVs and support renewable energy policies. Renewable energy knowledge has a positive impact on these two dependent variables. In addition, subjective and descriptive norms and $\mathrm{PBC}$ positively influence the intention to adopt renewable energy technologies, but have no significant effect on support for renewable energy policies. Implications of the results are discussed.
\end{abstract}

Keywords: China, Theory of Planned Behavior, renewable energy, alternative fuel vehicles, solar water heaters 


\section{Introduction}

The Chinese economic miracle has lifted millions out of poverty, but it has been costly for the environment. Energy consumption (and many other forms of resource use) has increased dramatically since the 1980s, and the resulting increases in air pollution and greenhouse gas (GHG) emissions have serious consequences for human health and the climate. To address these problems, China has initiated several national policies to move the country in the direction of a low carbon and sustainable growth economy [1-4]. For example, "The Twelfth Five-Year Plan" was initiated to reduce energy consumption and increase the use of renewable energy, and in turn to reduce $\mathrm{CO}_{2}$ emissions [2]. In addition, the "National Climate Change Programme" issued in 2007 was the first policy to deal with climate change [5] and the 2007 "Energy Conservation Law" was passed to enhance energy conservation in all industries [6]. In terms of the development and deployment of energy efficiency technologies, China has established specific energy strategies [4, 7-8]: China's "Renewable Energy Law," passed in 2005 and amended in 2009, was established to promote renewable energy technology research, development and production, and to mitigate environmental pollution [7-8]. Recently, China has also become the world's leader in the manufacture of wind turbines, solar water heaters (SWHs), and solar photovoltaic (PV) panels [9-11].

This study examines social-psychological factors affecting individuals' intention to adopt SWHs and alternative fuel vehicles (AFVs) and support for overall renewable energy policies in China. The main reason for focusing on SWH and AFV technologies is that the large-scale adoption of these two technologies will reduce the consumption of fossil fuels and thus carbon emissions [4, 11-14]. Solar technology requires no fossil fuels and produces little pollution in the 
manufacture, operation, and decommissioning processes; $\mathrm{CO}_{2}$ emissions produced from solar thermal energy are also minimal [13-14]. Thus, low-cost SWH technology can play a crucial role in clean energy development [13]. In addition, high efficiency AFVs are an effective means for reducing GHG emissions and air pollution in China and elsewhere [12, 15]. This is particularly important since the transportation sector is the fastest growing area of energy consumption in China $[12,16]$ and researchers estimate that there will be 400 million private vehicles in China by the year 2030 [12].

The residential solar power system, including both solar thermal and PV technologies, is considered to be a potential supplemental source of electricity in many Asian countries [18]. On average, SWH use could help residents reduce $50 \%$ to $80 \%$ of their water heating bills [19]. The installation fee of a SWH for 2 to 4 people in China is about $\$ 300$ to $\$ 1,000$, whereas the installation cost in the United States is $\$ 5,000$ to $\$ 10,000$ [13]. Currently, China is the leading country in SWH sales, accounting for more than $80 \%$ of the global market, followed by the United States, Germany, and Turkey; however, for per capita installation of SWH units, Cyprus leads, followed by Austria and Israel [20-21]. This means that the Chinese solar thermal market has continued growth potential [21].

The other focus of renewable energy technology in this study is AFV technology. AFVs include the technologies of pure electrical vehicles (EVs), plug-in hybrid electric vehicles (PHEVs), hybrid electric vehicles (HEVs), and hydrogen fuel cell vehicles [12]. This study focuses on pure EVs, PHEVs, and HEVs, and we use AFVs to refer to these three types of EVs for simplicity. Recent initiatives of the Chinese Energy Conservation and New-energy Vehicle Development Plan (2011-2020) aims to make China the world's leader in new-energy vehicle 
industrialization by 2020 [11]. The Chinese government provides subsidies of up to 60,000 Yuan $(\$ 9,800)$ for the purchase of a pure EV car and up to 50,000 Yuan $(\$ 8,100)$ for a plug-in vehicle [12]. In addition, the Chinese government initiated the Ten Cities-Thousand Vehicles Program to support the development of hybrid electric vehicles in ten cities each year [22]. Ambitious transportation energy plans like these, that focus on the promotion of AFVs, are expected to reduce fossil energy demand by approximately $22 \%$ and GHG emissions by $16.6 \%$ by the year 2050 [23]. Despite Chinese government efforts, the effect of these policies on customers' enthusiasm to purchase AFVs is still limited [24]. The government's target of increasing pilot cities from 10 to 25 has fallen significantly short recently [16], and there are still issues in cell technology, demand-side policies and preferences, subsidy rates, charging facilities, and regulation $[12,25]$. Consumers will not commit to AFVs in the long run unless they find significant value beyond the incentive of government subsidies.

\section{Social Acceptance of Renewable Energy Technology and Policy Support}

The rapid growth of renewable energy technology use in China can be traced directly to government policies. However, the importance of social psychological factors on individuals' renewable energy adoption behaviors cannot be neglected [11, 26-30]. Axsen and Kurani [28], for example, emphasize the impact of social networks (e.g., contagion, conformity, dissemination) on buyers' perceptions of PHEVs. In fact, more research is needed on the social and behavioral factors influencing customer's intention to adopt AFVs [11-12, 29]. In terms of successful implementation of SWHs, experts suggest increased public awareness of the benefits of solar thermal systems, as well as long-term policy support and incentives for market investment, especially for countries that have not widely adopted this technology [13]. As 
mentioned earlier, there is still room for increased per capita installation of SWHs in China. While technological innovations and tighter environmental regulations are necessary preconditions for improving energy efficiency, more attention needs to be paid to social and behavioral factors in energy efficiency and renewable energy adoption [12, 30-32], including the adoption of SWH and EV technologies.

Although researchers have focused on behavioral factors influencing energy efficiency in China $[1,11-12,33]$, more research is needed on the impact of social-psychological or customer demand factors associated with AFV and SWH technologies. Such research is necessary if policy makers are to increase renewable energy technology adoption and make renewable energy policies more effective [9, 11-12, 24]. Indeed, as Sovacool [34] notes: most energy studies focus on technological fixes rather than on human-centered energy use and environmental change. Social technical is a term that encompasses the technological, social, political, regulatory and cultural factors, deemed important in understanding public acceptance of renewable power and electricity consumption [35]. We contribute to the literature of social technical impediments to renewable energy adoption and related policy support by considering social psychological factors in this paper.

In sum, gaining a more comprehensive understanding of the factors influencing SWH and AFV adoption in China is especially important for policy and community efforts to reduce air pollution and GHG emissions given the fact that China is the world's leading emitter of carbon dioxide, having overtaken the United States in 2007 [3, 33, 36]. In addition, this paper provides theoretical and empirical implications for those countries that are developing SWH and AFV technologies and are interested in identifying the social factors influencing public acceptance of 
these technologies.

\section{The Theory of Planned Behavior}

This study adopts the theoretical framework of the Theory of Planned Behavior (TPB) [37], and aims to predict two different pro-environmental behaviors: adoption of SWHs and AFVs and support for renewable energy policies. These two behaviors differ in the level of self-interest involved and observability, and researchers have begun to investigate the distinct underlying conditions necessary to encourage various types of pro-environmental behaviors [38-39]. To our knowledge, few studies have investigated acceptance of these two technologies and perceived government policy support within the same model in one study.

The TPB framework has been successfully used to explain a variety of environmental behaviors or behavioral intentions [39-44] and renewable energy technology adoption intentions or behaviors, e.g., [24]. For example, Kaiser and Gutscher [45] found that the TPB variables explained $81 \%$ of the variance in conservation behavioral intentions. Furthermore, a recent study of wind farm opposition in Australia indicated that TPB variables explained approximately $58 \%$ of the variance in opposition to wind farms [46]. The TPB has also been used for examining individuals' policy support. For example, Wang, Zhang, and Zhang [47] found that energy-saving awareness and sense of social environment are the two most important predictors of public acceptance of tiered electricity price reform, which helps to reduce electricity consumption. In addition, Zhang, Fei, Zhang, and Liu [48] found that all three TPB variables significantly predicted public acceptance of the "Pay for Permit" policy, which helps reduce pollution around the Tai Lake area in China. 
The TPB assumes that human behavior is based on conscious and rational decisionmaking processes [37]. Behavioral intention is determined by three main factors: attitudes toward the behavior (i.e., overall evaluation of the behavior), beliefs about the normative expectation or perceived social pressure from significant others (i.e., subjective norms), and beliefs about the factors that may facilitate or hinder the performance of the behavior (i.e., perceived behavioral control, PBC). Scholars have suggested a consistently strong positive relationship between behavioral intention and behavior, e.g., [49]. Three commonly studied determinants of environmental behavior and behavioral intention include attitudes, subjective norms, and PBC (e.g., [50-51]). Although the evidence for the TPB is solid, researchers have suggested that an extended TPB model has better explanatory power in predicting the adoption of renewable energy technology [24] and other environmental behaviors [50]. Therefore, this study extends the TPB model by distinguishing between descriptive and injunctive norms and adding the factor of renewable energy knowledge, in addition to testing the influence of attitudes toward government's environmental protection actions. Given the difficulty of measuring actual behaviors in technology adoption at home and in public (e.g., AFVs, and EVs), we chose to use self-reported measures of intention to adopt technology and support for renewable energy as dependent variables.

\subsection{Attitudes toward environmental protection}

Proponents of the TPB consider attitudes to be an individual's favorable or unfavorable evaluation of a behavior in a given situation. A person is likely to evaluate the benefits and costs that may result from a specific behavior prior to performing that behavior. According to Ajzen [51], positive attitudes could affect an individual's intention to take action, and can also affect 
the level of innovation adoption [e.g., 52]. Recent research indicates that attitude factors are important predictors of solar power adoption [53], have a positive and direct impact on solar panel adoption intention [53], and are positively related to residents' intention to adopt electricity from renewable energy sources [54]. Several studies also report that positive attitudes increase households' willingness to pay for "green” energy [55] and "green" electricity [56]. Similarly, positive attitudes toward green electricity have the strongest effect on the intention to use green electricity products, followed by subjective norms and PBC [50]. Favorable attitudes about energy conservation or the environment are also found to be positively associated with the intention to reduce energy use [42], electricity saving activities [57], and other proenvironmental behaviors including fuel conservation and environmental organization membership [45].

Environmental concern, similar to environmental attitudes, which is considered to be a broad concept comprising a range of general environmental attitudes or synonymous with perceived consequences of environmental problems, has been widely studied [50, 58-63]. Research indicates a positive relationship between environmental concern and several proenvironmental behaviors, including willingness to accept energy-saving policies and energysaving measures [58-60], energy curtailment behaviors [61], and efficiency investments [62]. Although some research suggests a limited relationship between environmental concern and energy saving behaviors, the link between general environmental beliefs and pro-environmental behaviors is an important research topic $[41,44]$. Yet few researchers have investigated the relationship between environmental concern and environmental behaviors within the TPB framework and technology adoption (except for [50], and [44]). It is, therefore, important to 
examine the relationship between environment-related attitudes and technology adoption and policy support, especially in a country like China where renewable energy technology is developing rapidly and renewable energy policies have the potential for mitigating global climate change. This study investigates attitudes toward environmental protection that are inferred by individuals' positive or negative evaluation of using environmental resources, enforcing environmental laws, and manufacturing disposable products (e.g., plastic plates) in China. Later in this paper, we refer to attitudes toward environmental protection as "environmental attitudes" for purposes of simplicity. We hypothesize that there is a positive relationship between attitudes and the adoption of SWHs and AFVs and support for renewable energy policies.

\subsection{Subjective and descriptive norms of sustainable behaviors}

The influence of norms and social expectations on environmentally relevant behaviors is widely established [33, 46, 64-67]. Scholars have identified several types of norms, including subjective, descriptive, and injunctive norms $[64,68]$. The type of norm in the TPB is a subjective norm which is important in predicting energy saving or pro-environmental behaviors $[33,46,64,66,69]$.

Subjective norms are defined as perceived social pressure from significant others or beliefs about how significant others expect an individual to behave in a given situation [68]. Subjective norms are essential in encouraging or preventing people from investing in energy efficient technologies (e.g., [65]). Studies show that subjective norms are positively related with customers' intention to choose a "green" hotel [66] and other environmental conservation behaviors [67]. A recent study in China also reported that subjective norms have a positive impact on household electricity-saving behavior [33]. As for renewable energy, an Australian 
study concluded that subjective norms predicted the intention to oppose wind farms, partly due to the perceived pressures from family, friends, and neighbors [46]. Social norms and underlying social motives also play an important role in PV system purchase. Jager's [69] study indicated that the purchase of PV systems by neighbors/acquaintances was an important motive for people to purchase PV systems. However, conclusions regarding the influence of subjective norms on environmental behaviors have been inconsistent. Indeed, subjective norms were found to be an inadequate predictor of the intention to reduce energy use when attitudes and PBC were accounted for [51]. Several psychologists (e.g., [70-71]) argue that problems of conceptualizing and measuring subjective norms have reduced the ability to predict behavior and intention. Specifically, choosing the appropriate reference groups with which individuals strongly identify is essential for high predictive power on intention and behavior [71].

As an attempt to clarify the influence of norms on behaviors, Cialdini, Reno and Lallgren's [72] Focus Theory of Normative Conduct defined two distinct types of social norms: descriptive norms and injunctive norms. Descriptive norms were defined as the perceived prevalence of others' actual behavior, whereas injunctive norms refer to perceptions of approval or disapproval of behavior by others, which is in fact a type of subjective norm [73]. This study attempts to identity the distinct impact of subjective (i.e., injunctive) and descriptive norms on behaviors because they may have distinct effects on technology adoption and policy support. In particular, our study examines the normative influence of a specific reference group: close friends in the university setting, because college students experience a high level of social interaction in the university and their behavior and perceptions are generally influenced by friends. Specifically, subjective norms here refer to the perception of close friends' approval or 
disapproval of certain sustainable behaviors (e.g., saving electricity and water, and recycling). In addition, descriptive norms are defined as perceived prevalence of close friends' actual sustainable behaviors. Given the findings of previous research, this study proposes that subjective and descriptive norms, based on close friends' perspective and behaviors, will influence an individual's intention to adopt renewable energy technology and support renewable energy policies.

\subsection{Perceived behavioral control $(P B C)$ on energy conservation}

According to Ajzen, PBC is "the perceived ease or difficulty of performing the behavior" [37, p.122]. In addition, PBC is considered to be a function of control belief and perceived power of the control factors. A control belief indicates perceived presence of resources or opportunities, and perceived power refers to the evaluation of the importance of such resources or opportunities [74]. PBC has a direct effect on behavior and an indirect effect on behavior through intention.

That is, lacking the necessary ability to act will directly hinder individuals' decisions to behave regardless of the levels of favorable attitudes and social norms [68].

Research on energy conservation indicates that PBC has a positive impact on energy conservation intention [67], reduction of household energy use [42], purchase of green electricity products [50], and choice of a green hotel [66]. A study based on a 27-country sample indicated that $\mathrm{PBC}$ is the strongest predictor of willingness to sacrifice for the environment compared with other factors, such as perceived threat and environmental concern, which in turn affects a variety of pro-environmental behaviors (e.g. [75]). A recent study in China also demonstrated that PBC is positively associated with household residents' sustainable consumption behavior such as buying environment-friendly products [76]. As for renewable energy technology adoption, PBC 
is reported to be a positive mediator between attitudes and behaviors [77]. In terms of sustainable behaviors, Wang et al. [76] found that $\mathrm{PBC}$ is positively associated with several sustainable behavioral intentions (e.g., purchasing the environmental-friendly goods, willingness to pay more for environment-friendly products) and sustainable consumption behaviors (e.g., minimizing waste and improving resources efficiency) in China. Based on previous research, this study predicts that there is a positive relationship between PBC and renewable energy technology adoption and support for renewable energy policies.

\subsection{Perceived renewable energy knowledge}

Knowledge is the key in the formation of personal attitudes and behaviors [78-79], and it is an important factor influencing individuals' perceptions of global warming [80], proenvironmental or energy conservation behaviors [81-82], and attitudes toward renewable energy [83]. A meta-analysis by Bamberg and Moser [84] indicates that general environmental knowledge and specific knowledge about environmental problems are important indirect determinants (through the activation of responsibility, social norms, and guilt) of proenvironmental intention. Ngo et al. [85] assert that environmental knowledge is a significant and positive predictor of GHG reduction behaviors. Barr [86] found that knowledge of what and where to recycle has been significant in the successful implementation of recycling programs. Kaiser et al. [87] found that those who choose eco-friendly transportation have more environmental knowledge than those who prefer individual cars. In addition, environmental knowledge among adolescents was a significant moderator between the relationship between environmental attitudes and behaviors [88]. Energy saving knowledge and awareness of climate change are more likely to influence individuals' renewable energy purchases and participation in 
energy saving activities [89].

Knowledge about the functions and effects of technology can influence individuals' perceptions of the costs and benefits, which indirectly influence acceptance of a technology [30]. For example, scholars have found a positive relationship between knowledge and hydrogen technology acceptance [90] and adoption of renewable energy [83]. Consumers' confidence that "green" power is actually "green" is influenced by knowledge [91]. Evidence exists suggesting a negative relationship between knowledge level of a hazardous technology and trust in those who manage the technology and between perceived risks of the technology [92]. Furthermore, scholars have found that knowledge of relevant environmental concepts, environmental problems and action strategies for solving environmental problems has a significant indirect influence on the sustainable consumption behavior mediated by behavioral intention [93]. Feng and Reisner's study [38], however, demonstrates that knowledge is directly significant in explaining personal behaviors.

To our knowledge, few studies have examined the relationship between renewable energy knowledge, technology adoption behavior, and policy support within the TPB framework. Based on previous research, we expected perceived knowledge of renewable energy to have a positive impact on individuals' support for renewable energy policies and intention to adopt SWHs and AFVs. We adopted the concept of perceived knowledge, that is, familiarity with renewable energy (such as wind, solar and hydropower), to measure knowledge and predicted a positive relationship between perceived renewable energy knowledge and adoption of renewable energy technology and support for renewable energy policies.

\section{The present study}


This study investigates the influence of social-psychological factors, including three core TPB variables (attitudes, PBC, and subjective norms), descriptive norms, and perceived renewable energy knowledge, on the intention to adopt renewable energy technology and support renewable energy policies among Chinese college students. Based on the literature discussed earlier, we examined the following hypotheses (see Figure 1 for the proposed model): Hypothesis $1_{a}\left(\mathrm{H}_{1}\right)$ : Environmental attitudes have a positive effect on the intention to adopt renewable energy technology (i.e., SWHs and AFVs).

Hypothesis $1_{b}\left(\mathrm{H}_{\mathrm{b}}\right)$ : Environmental attitudes have a positive effect on support for renewable energy policies.

Hypothesis $2_{a}\left(\mathrm{H} 2_{\mathrm{a}}\right)$ : $\mathrm{PBC}$ on energy conservation has a positive effect on the intention to adopt renewable energy technology.

Hypothesis $2_{b}\left(\mathrm{H} 2_{\mathrm{b}}\right)$ : $\mathrm{PBC}$ on energy conservation has a positive effect on support for renewable energy policies.

Hypothesis $3_{a}\left(\mathrm{H} 3_{\mathrm{a}}\right)$ : Subjective norms of sustainable behaviors have a positive effect on the intention to adopt renewable energy technology.

Hypothesis $3_{b}\left(\mathrm{H}_{\mathrm{b}}\right)$ : Subjective norms of sustainable behaviors have a positive effect on support for renewable energy policies.

Hypothesis $4_{a}\left(\mathrm{H} 4_{\mathrm{a}}\right)$ : Descriptive norms of sustainable behaviors have a positive effect on the intention to adopt renewable energy technology.

Hypothesis $4_{b}\left(\mathrm{H} 4_{b}\right)$ : Descriptive norms of sustainable behaviors have a positive effect on support for renewable energy policies.

Hypothesis $5_{a}\left(\mathrm{H} 5_{\mathrm{a}}\right)$ : Perceived renewable energy knowledge has a positive effect on the 
intention to adopt renewable energy technology.

Hypothesis $5_{b}\left(\mathrm{H} 5_{\mathrm{b}}\right)$ : Perceived renewable energy knowledge has a positive effect on support for renewable energy policies.

[Figure 1 about here]

\section{Method}

\subsection{Participants}

Participants were recruited from a public university located on the southeastern coast of China. Students were randomly selected from the college of electrical engineering. A primary reason for choosing students from this college is that electrical engineering students are familiar with this study's topic. The rationale for choosing college students was twofold: to investigate the younger generation's view of renewable energy technology and policies and to understand a major group of future affluent energy consumers. Several scholars have argued that students' attitudes toward renewable energy are highly relevant because they are potential consumers of technology and possible domain experts [94]. Students from the southeastern coast of China were selected because the energy consumption of this region is among the highest in the country [40]. Six hundred and fifty-five participants completed a paper-and-pencil survey with a response rate of approximately $80 \%$. Participants $(74.50 \%$ were males) ranged in age from 17 to 23, with an average age of 19. The majority of students came from Jiangsu Province.

\subsection{Procedure}

A paper-and-pencil survey was used (instead of an Internet survey) because it was the least intrusive way of collecting data and ensures a high level of anonymity. The privacy concern of an Internet survey could be an issue in terms of how survey answers are being recorded since 
an Internet survey could be tracked through Internet Protocol (IP) addresses [95]. To ensure anonymity and reduce the chance of socially desirable responses for this study, personal identifiers were not collected. Participants answered a three-page questionnaire consisting of 22 items, requiring approximately 15 minutes to complete. The authors forward-translated the questionnaire into English, and then back-translated the questionnaire into Chinese. The backtranslated version was compared with the original version and items with discrepancies were revised. The process was repeated until the two versions essentially became identical [96]. All measures were based on a 5-point Likert-type scale, ranging from one (e.g., strongly disagree or most unlikely) to five (e.g., strongly agree or most likely). Composite measures of variables were created by averaging the response scores. See Table 1 for means and standard deviations (SDs) of all the items included in the measures.

[Table 1 about here]

\subsection{Measures}

\subsubsection{Attitudes toward environmental protection}

Three items were created to measure participants' attitudes toward environmental protection. These items focused on participants' beliefs about what actions should be taken or not taken in order to reduce negative environmental impacts. The three items included: "manufacturers should reduce the manufacturing of dispensable products," "abusive use of environmental resources will harm the wellbeing of the next generation," and "China needs more strict environmental laws." A higher score indicated a more positive attitude (Cronbach's alpha, $\alpha=.76)$.

\subsubsection{PBC on energy conservation}


To measure PBC on energy conservation, respondents were asked to assess the level of their perceived ability to conserve energy. Three statements were used: "I have control over how I consume or save energy," "If most of your classmates do not try to save energy, would you still take the initiative to save energy?" and "If there was no sufficient support from your friends for saving energy, would you still take the initiative to save energy?" A higher score indicated a higher degree of PBC $(\alpha=.77)$.

\subsubsection{Subjective norms of sustainable behaviors}

Three statements about the level of perceived support for sustainable behaviors among close friends were used to measure subjective norms. This concept is similar to injunctive norms. Items were adopted and modified from Read et al. [46], Abrahamse and Steg [97] and De Groot

and Steg [44]. Specifically, participants were asked to rate three statements regarding the extent to which the majority of their close friends think that they should save water, recycle, and save electricity. A higher score indicates a higher level of subjective norms $(\alpha=.90)$.

\subsubsection{Descriptive norms of sustainable behaviors}

Descriptive norms indicate individuals' perception of their close friends' actual sustainable behaviors. Participants were asked to rate how the majority of their close friends would perform behaviors including conserving electricity, conserving water, and purchasing products made from recycled materials. A higher score indicates a higher level of descriptive norms $(\alpha=.82)$.

\subsubsection{Perceived renewable energy knowledge}

Participants were asked to rate the level of their knowledge of solar power, wind power, and hydropower based on the level of their familiarity with each renewable energy technology. 
Although this measure did not assess participants' actual knowledge, perceived knowledge has been found to be associated with decision-making and behavior and to be correlated with actual knowledge [79]. A higher score indicates a higher level of renewable energy knowledge ( $\alpha=$ $.81)$.

\subsubsection{Intention to adopt renewable energy technology}

Two items assessing the intention of adopting SHWs and AFVs in the near future were created: "I will use a solar water heater at home" and "I will drive cars that rely on clean or renewable energy." A higher score indicates a higher degree of intention to adopt renewable technology (Spearman-Brown split-half coefficient $=.69)$.

\subsubsection{Support for government renewable energy policies}

Three statements were used to measure support for new government renewable energy policies: "The Chinese government should develop more solar energy technology," "The Chinese government should develop more wind energy technology," and "The Chinese government should encourage more research on renewable energy, such as hydrogen or clean coal energy." A higher score indicates a higher level of support for more government renewable energy policies $(\alpha=.80)$.

\section{Analytic strategy}

This study used Mplus (6.2) to analyze data [98] and followed Anderson and Gerbing's two-step approach of measurement validation [99]. Measurement validation using both exploratory (EFA) and confirmatory factor analyses (CFA) were first conducted prior to hypothesis tests [100]. Specifically, all measures were examined for uni-dimensionality, reliability, and validity. The SEM estimation of path coefficients was used to find the best-fitting 
model and test hypotheses. All of the SEM models were estimated from covariance matrices using the full information maximum likelihood (FIML) estimation procedure with manifest (measured) variables. Covariance values were estimated among all exogenous variables.

Measures of the overall model fit included the chi-square $\left(\chi^{2}\right)$ goodness-of-fit test statistic, the comparative fix index (CFI), the Tucker and Lewis index (TLI), the root mean square error of approximation (RMSEA), and the standardized root mean square residual (SRMR) [101].

\section{Results}

\subsection{Measurement model and CFA}

Prior to testing the measurement model, we screened the data to identify any violations of the general linear model assumptions. The measurement model had a good overall fit with $\chi^{2}$ of 372.46 with 149 degrees of freedom $\left(p<.0001 ; \chi^{2} / d . f .=2.50 ;\right.$ CFI $=.96$, TLI $=.95$, RMSEA $=$ $.05 ;$ CI [.042-.054]; SRMR = .04). Standardized loadings for latent factor indicators ranged from .60 to .91 (all $p$ 's $<.001$ ). All items were significantly associated with their specified constructs but not with others. The Composite Reliability (CR) and the Average Variance Extracted (AVE) were calculated. CRs of all latent variables were larger than 0.70 , indicating good internal consistency [102], except that the CR of intention to adopt renewable energy technologies was lower $(\mathrm{CR}=0.63)$. AVEs of all latent variables were larger than 0.50 , indicating good convergent validity [102], except that the AVE of intention to adopt renewable energy technologies was lower $(\mathrm{AVE}=0.46)$ (see Table 2$)$. We suspect that it was because only two items were used to measure the variable of intention and that these two items were related to two unique technologies, therefore convergent validity was small. To test the discriminant validity of the measurement model, this paper used the Maximum Shared Squared Variance (MSV) and the 
Average Squared Variance (ASV). All the results of MSVs and the ASVs were lesser than the corresponding AVEs, demonstrating good discriminant validity [101-102], except for the MSVs of the two DVs, suggesting that these two DVs share too much common variance. Based on the related nature of the two DVs, this paper specified them as correlated in the structural model.

[Table 2 about here]

\subsection{Structural relations}

The overall fit of the initial structural model yielded the following statistics: $\chi^{2}$ of 372.46 with 149 degrees of freedom $(p<.0001) ; \chi^{2} / d . f .=2.50 ; \mathrm{CFI}=.96, \mathrm{TLI}=.95, \mathrm{RMSEA}=.05$, 90\% CI [.042-.054]; SRMR = .04. As seen in Figure 2, results of the SEM demonstrated that the core constructs of TPB were all positively related to adoption intention. Specifically, environmental attitudes were positively associated with intention to adopt renewable energy technologies $(B=.32, p<.001)$ and support for renewable energy policies $(B=.41, p<.001)$. Therefore, $\mathrm{H} 1_{\mathrm{a}}$ and $\mathrm{H} 1_{\mathrm{b}}$ were supported. In addition, $\mathrm{PBC}$ had a positive effect on adoption intention $(B=.16, p<.001)$, however, it was not significantly related to support for renewable energy policies $(B=.06$, n.s. $)$, indicating support for $\mathrm{H} 2_{\mathrm{a}}$, but no support for $\mathrm{H} 2_{\mathrm{b}}$. Subjective norms were found to be positively related to adoption intention $(B=.17, p=.02)$, but not significantly related with support for renewable energy policies $(B=0.04, n . s$.$) . Therefore, \mathrm{H} 3_{\mathrm{a}}$ was supported, but $\mathrm{H} 3_{\mathrm{b}}$ was not supported.

Estimates of the SEM model indicated a positive relationship between descriptive norms and intention to adopt renewable energy technology $(B=.14, p=.03)$, but no relationship between descriptive norms and support for renewable energy policies $(B=.11, n . s$. $)$. These results suggest support for $\mathrm{H} 4$, but no support for $\mathrm{H} 4$ b. Finally, knowledge was positively related 
with intention to adopt renewable energy technology $(B=.14, p=.01)$, and with support for renewable energy policies $(B=.12, p=.01$. $)$. Results support H5a and H5b. Although it was not hypothesized, intention to adopt renewable energy technology had a positive relationship with support for renewable energy policies $(B=.56, p<.001)$.

[Figure 2 about here]

\section{Discussion and Conclusion}

This paper presents research results on the influence of three main TPB constructs: descriptive norms, and perceived renewable energy knowledge on Chinese college students' intention to adopt AFVs and SWHs and their support for government renewable energy policies. This project builds on previous work by verifying that the modified and extended TPB model performs well in predicting renewable energy adoption intention and policy support. Specifically, this study demonstrated the distinct roles played by two types of norms (subjective and descriptive norms), as well as the effect of perceived knowledge on renewable energy technology to extend the TPB framework.

This study used general measures or measures related to more familiar and observable behaviors among Chinese college students (e.g., saving electricity and recycling) for the independent variables rather than targeted specific behaviors - using SWHs and EVs and renewable energy policy support. The decision was based on several considerations: first, SWH and EV technologies have not become a part of college students' everyday life in China, and therefore questions directly addressing these technologies (e.g., "if most of my close friends think that I should drive an EV" or "if most of my close friends drive an EV") may sound distant or be unnatural to answer. In addition, one of our major goals was to predict future adoption 
intention and policy support from readily accessible variables, so using reliable measures that are general or related to more familiar behaviors is acceptable. Second, from an empirical perspective, using general or other related measures would yield similar results: Kaiser and Gutscher [45] found that the model with general measures did not differ with the models based on specific measures in both overall fit and path coefficients, except for the path between PBC and behaviors. They stated that even when the compatibility principle was fully violated (i.e., there was no behavioral overlap between the measures), $43 \%$ of the variance in behaviors could still be explained. Specifically, a few previous studies have used general environmental attitude (e.g., scores on the New Ecological Paradigm [NEP] scale [103]) to predict specific environmental behaviors including recycling [104], green product purchase [105], and energy conservation [106]. All three dimensions of NEP (balance of nature, limits to growth, and anthropocentrism) are in most cases not directly related to the target behaviors. Third, energy related attitudes or beliefs are derived from similar values [107] and measures across different domains of pro-environmental behaviors are likely to be related. For example, Berger [108] found that people who are actively engaged in recycling behaviors are more likely to use reusable shopping bags, fluorescent lights, and low-flow showerheads and toilets. Additionally, for most scales that measure environmental behaviors, the scores on their subscales are usually moderately related, e.g., [109].

The results reveal that attitudes toward environmental protection have a strong positive effect on both renewable energy technology adoption and policy support among all the predictors. This finding corroborates results of previous research in that altruistic attitudes (or environmental concern) are important determinants of intention to adopt hybrid EVs [24] and PV 
panels [54], and acceptance of green electricity [110]. Similar to results reported here, a recent study reported that environmental values had a positive impact on residents' intention to install a solar power system [18].

PBC on energy conservation is also an important predictor of individuals' intention to adopt renewable energy technologies; however, it was not associated with policy support. This result is consistent with Wang's [93] finding that PBC positively affects intention to adopt hybrid EVs in China, and it also highlights Ajzen's argument that the influence of belief regarding the difficulty to perform a behavior has a direct effect on behaviors [24]. The more the individuallevel factors (such as price, availability, and perceived ability) are associated with the adoption decision, the more likely such a behavioral intention will change [111]. Note that the measure of PBC here regards energy conservation in general, and therefore the result suggests that we can predict individuals' intention to adopt renewable technologies by this established and easy-tomeasure variable.

Similar to the results of attitudes, perceived renewable energy knowledge of solar, wind, and hydropower was positively related with both AFVs and SWH adoption and support for renewable energy policies. A previous study suggests that knowledge directly influences personal environmental behaviors in China [38], which is consistent with the current finding. In terms of AFV adoption, previous studies show the barriers of adopting EVs (e.g., customers' perceptions of lack of electric range, lack of vehicle chargers outside home) may cause the lack of individuals' knowledge for that technology [111]. Future research, therefore, should continue to explore how various aspects of customers' actual knowledge of AFVs affect behavioral intention and actual adoption behavior since this technology is still developing. 
In addition, this study indicates that subjective and descriptive norms of sustainable behaviors had positive effects on the intention to adopt renewable energy technologies, but no significant effect on support for renewable energy policies. Despite the fact that we measured norms across domains, the first half of the result is consistent with previous arguments suggesting that group norms are important determinants of attitudinal and behavioral changes, perhaps, even more so among college students [112]. A recent study on EV acceptance in China also demonstrated that the opinion of peers was positively associated with the willingness to purchase an EV [12]. These results may also reflect the collectivist culture of China, which is likely to be even stronger among college students because of the highly social nature of the university [113]. Thus, it is important for future research to examine social psychological theories, such as the TPB, in a variety of social or cultural contexts to determine the extent of their generalizability.

The finding that norms were a more important predictor of renewable energy technology adoption than the policy support may be due to the fact that supporting renewable energy policies is less observable by others and less subject to social sanctions. In contrast, renewable energy technology adoption is more observable (such as driving an EV); therefore, social rewards for conforming (or sanctions for not conforming) to a group norm are more salient. In other words, the influence of norms is moderated by whether the behavior is enacted in a public or private setting $[72,114]$ (or to what extent the behavior is likely to be observed by others [115-116]). This finding is in line with that of previous literature and suggests that different drivers promote different types of pro-environmental behaviors. However, it is also possible that the norms of sustainable behaviors just have more to do with technology adoption intention than 
with policy support.

Overall, the predictors explained individuals' intention to adopt SWH and AFV technologies, but not support for renewable energy policies. This finding may be due partially to the uniqueness of that behavior domain. Similar results were also reported in the literature. For example, the perceived importance of environmental protection is positively related with individuals' environmental resource conservation behaviors, but not with public advocacy behaviors [38]. Future research should continue to investigate various social-psychological factors affecting pro-environmental behaviors in different domains.

\section{Limitations and Suggestions for Future Research}

This study has several limitations that need to be mentioned. The use of college students limits the generalizability of findings. However, the value of studying college students is that students may have a greater impact on future energy use due to their education level and exposure to renewable energy information on campus. In particular, examining the adoption of AFVs or EVs among college students will have important positive impacts on the society to reduce future global carbon emissions. However, participants were volunteers and they may have a special interest in renewable energy issues, which possibly influenced their responses.

The causal nature of the observed relationships cannot be established due to the use of a cross-sectional design. It is difficult to determine if acceptance of renewable energy technology may also influence individuals' information uptake and perceived knowledge, rather than the other way around. Future research with longitudinal measurements or an experimental design would facilitate a clearer understanding of the complex factors that influence decisions to adopt renewable energy technologies and support renewable energy policies. In terms of measurement, 
this study used only two items to measure renewable energy technology adoption; future researchers may gain additional insights by investigating various types of renewable energy technologies and with more items. Lastly, knowledge here was measured as perceived familiarity with renewable energy technologies. Future studies could provide some validation questions to test individuals' actual knowledge and to compare the difference between perceived and actual knowledge.

The main implication of this study pertains to renewable energy education not only in China but also in western counties. Environmental education programs designed to increase awareness and knowledge of renewable energy technology (emphasizing PBC and diffusing, and reinforcing pro-environmental norms) may play an important role in promoting renewable energy technology and policy support. Findings reported here also demonstrate that focusing on the diffusion of normative messages of sustainable behaviors could be an effective way to promote clean and renewable technology. Future research could investigate the effectiveness of combining both injunctive and descriptive normative messages in promoting renewable energy adoption across different organizational and cultural contexts. As previous studies suggest, the effect of combining these two types of normative messages has been proven to be stronger than their additive effects on self-reported pro-environmental behavior [117]. Importantly, widespread use of information on promoting renewable energy knowledge should be part of effective interventions to stimulate individuals' renewable technology adoption.

In summary, research devoted to promoting renewable energy adoption and policy support will benefit from the investigation of how to promote or change attitudes toward environmental protection, subjective norms, descriptive norms, $\mathrm{PBC}$, and renewable energy 
knowledge in the light of the extended TPB model. Future research should also explore the importance of assessing social-psychological predictors of acceptance of renewable energy technologies and policies in a wide variety of group, organizational, or cultural contexts.

\section{Acknowledgements}

This work was supported in part by the Engineering Research Center Program of the National Science Foundation and the Department of Energy under NSF Award Number EEC-1041877 and the CURENT Industry Partnership Program. The authors would like to thank Yang Li from South East University, China for assistance with data collection and Erica Davis and Erin Wills for providing useful suggestions that improved the manuscript. 


\section{References}

[1] Jiang, P., Chen, Y., Xu, B., Dong, W., \& Kennedy, E. (2013). Building low carbon communities in China: The role of individual's behaviour change and engagement. Energy Policy 60, 611620. doi:10.1016/j.enpol.2013.05.017.

[2] The central government of People's Republic of China. (2011). National economic and social development twelfth five-year plan. Retrieved from http://www.gov.cn/2011lh/content_1825838.html.

[3] Wang, Q. (2010). Effective policies for renewable energy: The example of China's wind powerlessons for China photovoltaic power. Renewable and Sustainable Energy Reviews, 14, 702-712.

[4] Energy Research Institute of National Development and Reform Commission. (2015). China 2050 high renewable energy penetration scenario and roadmap study. Retrieve from http://www.efchina.org/Attachments/Report/report-20150420/China-2050-High-RenewableEnergy-Penetration-Scenario-and-Roadmap-Study-Executive-Summary.pdf.

[5] National development and reform commission of China. (2007). China's National Climate Change Programme. Retrieved from http://www.ccchina.gov.cn/WebSite/CCChina/UpFile/File188.pdf.

[6] The standing committee of the national people's congress of China. (2007). The Revised Energy Conservation Law of the People's Republic of China. Retrieved from http://www.lawinfochina.com/law/display.asp?db=1\&id=6467.

[7] Schuman, S., \& Lin, A. (2012). China's Renewable Energy Law and its impact on renewable power in China: Progress, challenges and recommendations for improving implementation. Energy Policy, 51, 89-109. doi:10.1016/j.enpol.2012.06.066.

[8] Wang, Z., Qin, H., \& Lewis, J. I. (2012). China's wind power industry: Policy support, technological achievements, and emerging challenges. Energy Policy, 51, 80-88. doi:10.1016/j.enpol.2012.06.067.

[9] Chinese wind energy association. (2012). Statistics of capacity of China's wind turbine 2011. Retrieved from http://www.cwea.org.cn/upload/2011\%E5\%B9\%B4\%E9\%A3\%8E\%E7\%94\%B5\%E8\%A3\%85 $\%$ E69C\%BA\%E5\%AE\%B9\%E9\%87\%8F\%E7\%BB\%9F\%E8\%AE\%A1.pdfS.

[10] Wang, Z. Y., Ren, D. M., \& Gao, H. (2011). China renewable energy industry development report. Beijing, China: Chemical Industry Press.

[11] Yuan, X., Zuo, J., \& Ma, C. (2011). Social acceptance of solar energy technologies in ChinaEnd users' perspective. Energy Policy, 39(3), 1031-1036. doi:10.1016/j.enpol.2011.01.003.

[12] Zhang, Y., Yu, Y., \& Zou, B. (2011). Analyzing public awareness and acceptance of alternative fuel vehicles in China: The case of EV. Energy Policy, 39(11), 7015-7024. doi:10.1016/j.enpol.2011.07.055. 
[13] Hudon, K., Merrigan, T., Burch J., \& Maguire, J. (2012). Low-cost solar water heating research and development roadmap. National Renewable Energy Laboratory. Department of Energy. Retrieved from http://www.nrel.gov/docs/fy12osti/54793.pdf

[14] International Energy Agency. (2009). Renewable energy essentials: Solar heating and cooling. Retrieved from http://www.iea.org/publications/freepublications/publication/solar_heating_cooling.pdf.

[15]International Energy Agency. (2013). Global EV outlook. Retrieved from https://www.iea.org/publications/freepublications/publication/global-ev-outlook.html.

[16] Marquis, C., Xhang, H., \& Zhou, L. (2013). China's quest to adopt electric vehicles. Stanford Social Innovation Review, 11(2), 52-57.

[17] European Commission European Research Area (2012). Case 5: China takes the lead in electric vehicles deployment. Retrieved from http://www.polinares.eu/docs/d31/polinares_wp3 case5.pdf.

[18] Chen, K. K. (2014). Assessing the effects of customer innovativeness, environmental value and ecological lifestyles on residential solar power systems install intention. Energy Policy, 67, 951961. doi:10.1016/j.enpol.2013.12.005.

[19] Department of Energy. (2014). Everything you wanted to know about solar water heating systems. Retrieved from http://www.energy.gov/energysaver/articles/everything-you-wantedknow-about-solar-water-heating-systems.

[20] Renewable Energy Policy Network for the $21^{\text {st }}$ Century (2014). Renewables 2014: Global status report. Retrieved from http://www.ren21.net/Portals/0/documents/Resources/GSR/2014/GSR2014_KeyFindings_low\%2 Ores.pdf.

[21] Mauthner, F., \& Weiss, W. (2014). Solar heat worldwide. International Energy Agency. Solar Heating \& Cooling Programme. Retrieved from http://www.ieashc.org/data/sites/1/publications/Solar-Heat-Worldwide-2014.pdf.

[22] Hu, X., Chang, S., Li, J., \& Qin, Y. (2010). Energy for sustainable road transportation in China: Challenges, initiatives and policy implications. Energy, 35(11), 4289-4301. doi:10.1016/j.energy.2009.05.024.

[23] Ou, X., Yan, X., \& Zhang, X. (2010). Using coal for transportation in China: Life cycle GHG of coal-based fuel and electric vehicle, and policy implications. International Journal of Greenhouse Gas Control, 4(5), 878-887. doi:10.1016/j.ijggc.2010.04.018.

[24] Wang, S., Fan, J., Zhao, D., Yang, S., \& Fu, Y. Predicting consumers' intention to adopt hybrid electric vehicles: using an extended version of the theory of planned behavior model.

Transportation, 1-21. doi:10.1007/s11116-014-9567-9.

[25] Roche, M.Y., Mourato, S., Fischedick, M., Pietzner, K., \& Viebahn, P., (2010). Public attitudes towards and demand for hydrogen and fuel cell vehicles: a review of the evidence and methodological implications. Energy Policy, 38 (10), 5301-5310.

[26] Mallett, A. (2007). Social acceptance of renewable energy innovations: The role of technology 
cooperation in urban Mexico. Energy Policy, 35(5), 2790-2798. doi:10.1016/j.enpol.2006.12.008

[27] Wüstenhagen, R., Wolsink, M., \& Bürer, M. J. (2007). Social acceptance of renewable energy innovation: An introduction to the concept. Energy Policy, 35(5), 2683-2691.

doi:10.1016/j.enpol.2006.12.001.

[28] Axsen, J. and Kurani, K. S. (2012). Interpersonal influence within car buyers' social networks: applying five perspectives to plug-in hybrid vehicle drivers. Environment and Planning, Part-A 44(5), 1047-1065.

[29] Turrentine, T. S., Garas, D., Lentz, A., \& Woodjack, J. (2011). The UC Davis MINIE Consumer Study. Institute of Transportation Studies, University of California, Davis. Research Report UCDITS-RR-11-05.

[30] Huijts, N. M. A., Molin, E. J. E., \& Steg, L. (2012). Psychological factors influencing sustainable energy technology acceptance: A review-based comprehensive framework. Renewable and Sustainable Energy Reviews, 16(1), 525-531. doi:10.1016/j.rser.2011.08.018

[31] Dietz, T., Gardner, G. T., Gilligan, J., Stern, P. C., \& Vandenbergh, M. P. (2009). Household actions can provide a behavioral wedge to rapidly reduce US carbon emissions. Proceedings of the National Academy of Sciences, 106(44), 18452-18456. doi: 10.1073/pnas.0908738106

[32] Steg, L., Dreijerink, L., \& Abrahamse, W. (2005). Factors influencing the acceptability of energy policies: A test of VBN theory. Journal of environmental psychology, 25(4), 415-425.

doi:10.1016/j.jenvp.2005.08.003

[33]Wang, Z., Zhang, B., Yin, J., \& Zhang, Y. (2011). Determinants and policy implications for household electricity-saving behaviour: Evidence from Beijing, China. Energy Policy, 39(6), 3550-3557. doi:10.1016/j.enpol.2011.03.055

[34] Sovacool, B. K. (2014). What are we doing here? Analyzing fifteen years of energy scholarship and proposing a social science research agenda. Energy Research and Social Science, 1, 1-29.

[35] Sovacool, B. K. (2009). Rejecting renewables: The socio-technical impediments to renewable electricity in the United States. Energy Policy, 37(11), 4500-4513.

[36] International Energy Agency. (2014). Key world energy statistics 2014. Retrieved from http://www.iea.org/newsroomandevents/agencyannouncements/key-world-energy-statistics2014-now-available-for-free.html.

[37] Ajzen, I. (1991). The theory of planned behavior. Organizational Behavior and Human Decision Processes, 50(2), 179-211. doi:10.1016/0749-5978(91)90020-T

[38] Feng, W., \& Reisner, A. (2011). Factors influencing private and public environmental protection behaviors: Results from a survey of residents in Shaanxi, China. Journal of environmental management, 92(3), 429-436. doi:10.1016/j.jenvman.2010.08.002.

[39] Griskevicius, V., Tybur, J. M., \& Van den Bergh, B. (2010). Going green to be seen: Status, reputation, and conspicuous conservation. Journal of Personality and Social Psychology, 98(3), 392-404.

[40] Chen, C. F., \& Knight, K. (2014). Energy at work: Social psychological factors affecting energy conservation intentions within Chinese electric power companies. Energy Research \& Social 
Science, 4, 23-31. doi:10.1016/j.erss.2014.08.004.

[41] Scherbaum, C. A., Popovich, P. M., \& Finlinson, S. (2008). Exploring individual- level factors related to employee energy- conservation behaviors at work. Journal of Applied Social Psychology, 38(3), 818-835. doi: 10.1111/j.1559-1816.2007.00328.x.

[42] Abrahamse, W., \& Steg, L. (2011). Factors related to household energy use and intention to reduce it: The role of psychological and socio-demographic variables. Human Ecology Review, 18(1), 30-40.

[43] Harland, P., Staats, H., \& Wilke, H. A. (1999). Explaining proenvironmental intention and behavior by personal norms and the theory of planned behavior1. Journal of Applied Social Psychology, 29(12), 2505-2528. doi: 10.1111/j.1559-1816.1999.tb00123.x.

[44] De Groot, J., \& Steg, L. (2007). General beliefs and the theory of planned behavior: The role of environmental concerns in the TPB. Journal of Applied Social Psychology, 37(8), 1817-1836. doi: 10.1111/j.1559-1816.2007.00239.x.

[45] Kaiser, F. G., \& Gutscher, H. (2003). The proposition of a general version of the theory of planned behavior: Predicting ecological behavior. Journal of Applied Social Psychology, 33(3), 586-603. doi: 10.1111/j.1559-1816.2003.tb01914.x.

[46] Read, D. L., Brown, R. F., Thorsteinsson, E. B., Morgan, M., \& Price, I. (2013). The theory of planned behaviour as a model for predicting public opposition to wind farm developments. Journal of Environmental Psychology, 36, 70-76. doi:10.1016/j.jenvp.2013.07.001.

[47] Wang, Z., Zhang, B., \& Zhang, Y. (2012). Determinants of public acceptance of tiered electricity price reform in China: Evidence from four urban cities. Applied Energy, 91(1), 235-244. doi:10.1016/j.apenergy.2011.09.002.

[48] Zhang, B., Fei, H., Zhang, Y., \& Liu, B. (2015). Regulatory uncertainty and corporate pollution control strategies: An empirical study of the 'Pay for Permit' policy in the Tai Lake Basin. Environment and Planning C: Government and Policy, 33(1), 118-135.

[49] Armitage, C. J., \& Conner, M. (2001). Efficacy of the theory of planned behaviour: A meta- analytic review. British journal of social psychology, 40(4), 471-499.

doi: 10.1348/014466601164939.

[50] Bamberg, S. (2003). How does environmental concern influence specific environmentally related behaviors? A new answer to an old question. Journal of environmental psychology, 23(1), 21-32. doi:10.1016/S0272-4944(02)00078-6.

[51] Ajzen, I. (2001). Nature and operation of attitudes. Annual review of psychology, 52(1), $27-58$. doi: 10.1146/annurev.psych.52.1.27.

[52] Faiers, A., \& Neame, C. (2006). Consumer attitudes towards domestic solar power systems. Energy Policy, 34(14), 1797-1806. doi:10.1016/j.enpol.2005.01.001.

[53] Claudy, M. C., Peterson, M., \& O'Driscoll, A. (2013). Understanding the attitude-behavior gap for renewable energy systems using behavioral reasoning theory. Journal of Macromarketing. 33(4), 273-287. doi: 10.1177/0276146713481605.

[54] Paladino, A., \& Baggiere, J. (2008). Are we 'green'? An empirical investigation of renewable 
electricity consumption. European Advances in Consumer Research, 8, 340-341.

[55] Wiser, R. H. (2007). Using contingent valuation to explore willingness to pay for renewable energy: A comparison of collective and voluntary payment vehicles. Ecological economics, 62(3), 419-432. doi:10.1016/j.ecolecon.2006.07.003.

[56] Hansla, A., Gamble, A., Juliusson, A., \& Gärling, T. (2008). Psychological determinants of attitude towards and willingness to pay for green electricity. Energy Policy, 36(2), 768-774. doi:10.1016/j.enpol.2007.10.027.

[57] Ek, K., \& Söderholm, P. (2010). The devil is in the details: Household electricity saving behavior and the role of information. Energy Policy, 38(3), 1578-1587. doi:10.1016/j.enpol.2009.11.041.

[58] Poortinga, W., Steg, L., \& Vlek, C. (2004). Values, environmental concern, and environmental behavior a study into household energy use. Environment and Behavior, 36(1), 70-93. doi: 10.1177/0013916503251466.

[59] Steg, L., Dreijerink, L., \& Abrahamse, W. (2005). Factors influencing the acceptability of energy policies: A test of VBN theory. Journal of environmental psychology, 25(4), 415-425. doi:10.1016/j.jenvp.2005.08.003.

[60] Steg, L., De Groot, J. I., Dreijerink, L., Abrahamse, W., \& Siero, F. (2011). General antecedents of personal norms, policy acceptability, and intentions: The role of values, worldviews, and environmental concern. Society and Natural Resources, 24(4), 349-367. doi:10.1080/08941920903214116.

[61] Barr, S., Gilg, A. W., \& Ford, N. (2005). The household energy gap: Examining the divide between habitual-and purchase-related conservation behaviours. Energy Policy, 33(11), 1425 1444. doi:10.1016/j.enpol.2003.12.016.

[62] Whitmarsh, L., \& O'Neill, S. (2010). Green identity, green living? The role of pro-environmental self-identity in determining consistency across diverse pro-environmental behaviours. Journal of Environmental Psychology, 30(3), 305-314. doi:10.1016/j.jenvp.2010.01.003.

[63] Carlsson- Kanyama, A., Lindén, A. L., \& Eriksson, B. (2005). Residential energy behaviour: Does generation matter? International Journal of Consumer Studies, 29(3), 239-253. doi: 10.1111/j.1470-6431.2005.00409.x.

[64] Nolan, J. M., Schultz, P. W., Cialdini, R. B., Goldstein, N. J., \& Griskevicius, V. (2008). Normative social influence is underdetected. Personality and Social Psychology Bulletin, 34(7), 913-923. doi: 10.1177/0146167208316691.

[65] Claudy, M., \& O'Driscoll, A. (2008). Beyond economics: A behavioural approach to energy efficiency in domestic buildings. Euro - Asian Journal of Sustainable Energy Development Policy, 1, 27-40.

[66] Han, H., Hsu, L. T. J., \& Sheu, C. (2010). Application of the theory of planned behavior to green hotel choice: Testing the effect of environmental friendly activities. Tourism Management, 31(3), 325-334. doi:10.1016/j.tourman.2009.03.013.

[67] Kaiser, F. G., Hübner, G., \& Bogner, F. X. (2005). Contrasting the theory of planned behavior with the Value- Belief- Norm model in explaining conservation behavior. Journal of Applied 
Social Psychology, 35(10), 2150-2170. doi: 10.1111/j.1559-1816.2005.tb02213.x.

[68] Jager, W. (2006). Stimulating the diffusion of photovoltaic systems: A behavioural perspective. Energy Policy, 34(14), 1935-1943. doi:10.1016/j.enpol.2004.12.022.

[69] Fishbein, M., \& Ajzen, I. (1975). Belief, attitude, intention and behavior: An introduction to theory and research. Boston, MA: Addison-Wesley.

[70] Louis, W., Davies, S., Smith, J., \& Terry, D. (2007). Pizza and pop and the student identity: The role of referent group norms in healthy and unhealthy eating. The Journal of Social Psychology, 147(1), 57-74. doi: 10.3200/SOCP.147.1.57-74.

[71] Louis, W. R., Taylor, D. M., \& Douglas, R. L. (2005). Normative influence and rational conflict decisions: Group norms and cost-benefit analyses for intergroup behavior. Group Processes \& Intergroup Relations, 8(4), 355-374. doi: 10.1177/1368430205056465.

[72] Cialdini, R. B., Reno, R. R., \& Kallgren, C. A. (1990). A focus theory of normative conduct: Recycling the concept of norms to reduce littering in public places. Journal of Personality and Social Psychology, 58(6), 1015. doi: http://dx.doi.org/10.1037/0022-3514.58.6.1015.

[73] Rivis, A., \& Sheeran, P. (2003). Descriptive norms as an additional predictor in the theory of planned behaviour: A meta-analysis. Current Psychology, 22(3), 218-233. doi: 10.1007/s12144003-1018-2.

[74] Ajzen, I., \& Madden, T. J. (1986). Prediction of goal-directed behavior: Attitudes, intentions, and perceived behavioral control. Journal of Experimental Social Psychology, 22(5), 453-474. doi:10.1016/0022-1031(86)90045-4.

[75] Oreg, S., \& Katz-Gerro, T. (2006). Predicting proenvironmental behavior cross-nationally values, the theory of planned behavior, and value-belief-norm theory. Environment and Behavior, 38(4), 462-483. doi: 10.1177/0013916505286012.

[76] Wang, P., Wu, W., Zhu, B., \& Wei, Y. (2013). Examining the impact factors of energy-related $\mathrm{CO}_{2}$ emissions using the STIRPAT model in Guangdong province, China. Applied Energy, 106, 65-71. doi:10.1016/j.apenergy.2013.01.036.

[77] Alam, S. S., \& Rashid, M. (2013). Intention to use renewable energy: Mediating role of attitude. Energy Research Journal, 3(2), 37.

[78] Mainieri, T., Barnett, E. G., Valdero, T. R., Unipan, J. B., \& Oskamp, S. (1997). Green Buying: The Influence of Environmental Concern on Consumer Behavior. Journal of Social Psychology, 137(2), 189-204. doi:10.1080/00224549709595430.

[79] Radecki, C. M., \& Jaccard, J. (1994). Perceptions of knowledge, actual knowledge and information search behavior. Journal of Experimental Social Psychology, 31, 107-138.

[80] Truelove, H. B., \& Parks, C. (2012). Perceptions of behaviors that cause and mitigate global warming and intentions to perform these behaviors. Journal of Environmental Psychology, 32(3), 246-259. doi:10.1016/j.jenvp.2012.04.002.

[81] Gatersleben, B., Steg, L., \& Vlek, C. (2002). Measurement and determinants of environmentally significant consumer behaviour. Environment and Behavior, 34(3), 335-362. doi:

10.1177/0013916502034003004. 
[82] Kaiser, F. G., \& Fuhrer, U. (2003). Ecological behavior's dependency on different forms of knowledge. Applied Psychology, 52(4), 598-613. doi: 10.1111/1464-0597.00153htt.

[83] Arkesteijn, K., \& Oerlemans, L. (2005). The early adoption of green power by Dutch households: An empirical exploration of factors influencing the early adoption of green electricity for domestic purposes. Energy Policy, 33(2), 183-196. doi:10.1016/S0301-4215(03)00209-X.

[84] Bamberg, S., \& Möser, G. (2007). Twenty years after Hines, Hungerford, and Tomera: A new meta-analysis of psycho-social determinants of pro-environmental behaviour. Journal of Environmental Psychology, 27(1), 14-25. doi:10.1016/j.jenvp.2006.12.002.

[85] Ngo, A. T., West, G. E., \& Calkins, P. H. (2009). Determinants of environmentally responsible behaviours for greenhouse gas reduction. International Journal of Consumer Studies, 33(2), 151161. doi: 10.1111/j.1470-6431.2009.00763.x.

[86] Barr, S. (2003). Strategies for sustainability: Citizens and responsible environmental behaviour. Area, 35(3), 227-240. doi: 10.1111/1475-4762.00172.

[87] Kaiser, F. G., Ranney, M., Hartig, T., \& Bowler, P. A. (1999). Ecological behavior, environmental attitude, and feelings of responsibility for the environment. European Psychologist, 4(2), 59-74. doi: http://dx.doi.org.proxy.lib.utk.edu:90/10.1027//1016-9040.4.2.59.

[88] Meinhold, J. L., \& Malkus, A. J. (2005). Adolescent environmental behaviors: Can knowledge, attitudes, and self-efficacy make a difference? Environment and Behavior, 37(4), 511-532. doi: 10.1177/0013916504269665.

[89] Zografakis, N., Sifaki, E., Pagalou, M., Nikitaki, G., Psarakis, V., \& Tsagarakis, K. P. (2010). Assessment of public acceptance and willingness to pay for renewable energy sources in Crete. Renewable and Sustainable Energy Reviews, 14(3), 1088-1095. doi:10.1016/j.rser.2009.11.009.

[90] O'Garra, T., Mourato, S., \& Pearson, P. (2008). Investigating attitudes to hydrogen refuelling facilities and the social cost to local residents. Energy policy, 36(6), 2074-2085. doi:10.1016/j.enpol.2008.02.026.

[91] Salmela, S., \& Varho, V. (2006). Consumers in the green electricity market in Finland. Energy Policy, 34(18), 3669-3683. doi: http://dx.doi.org/10.1016/j.enpol.2005.08.008.

[92] Siegrist, M., \& Cvetkovich, G. (2000). Perception of hazards: The role of social trust and knowledge. Risk Analysis, 20(5), 713-720. doi: 10.1111/0272-4332.205064.

[93] Wang, P., Liu, Q., \& Qi, Y. (2014). Factors influencing sustainable consumption behaviors: A survey of the rural residents in China. Journal of Cleaner Production, 63, 152-165. doi:10.1016/j.jclepro.2013.05.007.

[94] Qu, M., Ahponenb, P.,Tahvanainena, L., Grittena, D., Mola-Yudegoa, B., \& Pelkonen, P. (2011). Chinese university students' knowledge and attitudes regarding forest bio-energy. Renewable and Sustainable Energy Reviews, 15(8), 3649-3657.

[95] Porter, S.R. (2004). Pros and cons of paper and electronic surveys. In S. R. Porter (Ed.), Overcoming survey research problems. New Directions for Institutional Research, no. 121 (pp. 91-98). San Francisco: Jossey-Bass.

[96] Ercikan, K. (1998). Translation Effects in International Assessments. International Journal of 
Educational Research, 29, 543-553.

[97] Abrahamse, W., \& Steg, L. (2009). How do socio-demographic and psychological factors relate to households' direct and indirect energy use and savings? Journal of economic psychology, 30(5), 711-720.

[98] Muthén, L. K., \& Muthén, B. O. (2010). Mplus user's guide: Statistical analysis with latent variables. Los Angeles, CA: Muthén \& Muthén.

[99] Anderson, J. C., \& Gerbing, D. W. (1992). Assumptions and comparative strengths of the twostep approach comment on Fornell and Yi. Sociological Methods \& Research, 20(3), 321-333. doi: 10.1177/0049124192020003002.

[100] Brown, T. A. (2014). Confirmatory factor analysis for applied research. New York, NJ: Guilford Publications.

[101] Fornell, C., \& Larcker, D. F. (1981). Evaluating structural equation models with unobservable variables and measurement error. Journal of Marketing Research, 18(1), 39-50.

[102] Hair, J. F., Black, W. C., Babin, B. J., \& Anderson, R. E. (2010). Multivariate data analysis: A global perspective. 7th ed. Upper Saddle River: Pearson Prentice Hall Publishing.

[103] Dunlap, R. E., Van Liere, K. D., Mertig, A. G., \& Jones, R. E. (2000). New trends in measuring environmental attitudes: measuring endorsement of the new ecological paradigm: a revised NEP scale. Journal of Social Issues, 56(3), 425-442.

[104] Kurz, T., Linden, M., \& Sheehy, N. (2007). Attitudinal and community influences on participation in new curbside recycling initiatives in Northern Ireland. Environment and Behavior, 39(3), 367-391.

[105] Pickett-Baker, J., \& Ozaki, R. (2008). Pro-environmental products: marketing influence on consumer purchase decision. Journal of Consumer Marketing, 25(5), 281-293.

[106] Poortinga, W., Steg, L., \& Vlek, C. (2002). Environmental risk concern and preferences for energy-saving measures. Environment and behavior, 34(4), 455-478.

[107] Stern, P. C., Dietz, T., Abel, T. D., Guagnano, G. A., \& Kalof, L. (1999). A value-belief-norm theory of support for social movements: The case of environmentalism. Human Ecology Review, $6(2), 81$.

[108] Berger, I. E. (1997). The demographics of recycling and the structure of environmental behavior. Environment and Behavior, 29(4), 515-531.

[109] Tobler, C., Visschers, V. H., and Seigrist, M. (2012). Addressing climate change: Determinants of consumers' willingness to act and to support policy measures. Journal of Environmental Psychology, 32, 197-207.

[110] Kotchen, M. J., \& Moore, M. R. (2007). Private provision of environmental public goods: Household participation in green-electricity programs. Journal of Environmental Economics and Management, 53(1), 1-16. doi: 10.1016/j.jeem.2006.06.003.

[111] Sovacool, B. K., \& Hirsh, R. F. (2009). Beyond batteries: An examination of the benefits and barriers to plug-in hybrid electric vehicles (PHEVs) and a vehicle-to-grid (V2G) transition. Energy Policy, 37(3), 1095-1103. doi:10.1016/j.enpol.2008.10.005. 
[112] Neighbors, C., Lee, C. M., Lewis, M. A., Fossos, N., \& Larimer, M. E. (2007). Are social norms the best predictor of outcomes among heavy-drinking college students? Journal of Studies on Alcohol and Drugs, 68(4), 556-565.

[113] Bagozzi R. P., Baumgartner, H., Pieters, R., \& Zeelenberg, M. (2000). The role of emotions in goal-directed behavior. In S. Ratneshwar, D. G. Mick, \& C. Huffman (Eds.), The why of consumption: Contemporary perspectives on consumer motives, goals, and desires (pp. 36-58). New York, NJ: Routledge.

[114] Lapinski, M. K., \& Rimal, R. N. (2005). An explication of social norms. Communication Theory, 15(2), 127-147. doi: 10.1111/j.1468-2885.2005.tb00329.x.

[115] Green, T. \& Peloza, J. (2014). Finding the right shade of green: The effect of advertising appeal type on environmentally friendly consumption. Journal of Advertising, 43(2), 128-141, doi:10.1080/00913367.2013.834805.

[116] Tang, Z., Chen, X., \& Luo, J. (2011). Determining socio-psychological drivers for rural household recycling behavior in developing countries: A case study from Wugan, Hunan, China. Environment and Behavior, 43(6), 848-877. doi: 10.1177/0013916510375681.

[117] De Groot, J. I., Abrahamse, W., \& Jones, K. (2013). Persuasive normative messages: The influence of injunctive and personal norms on using free plastic bags. Sustainability, 5(5), 18291844. doi:10.3390/su5051829. 


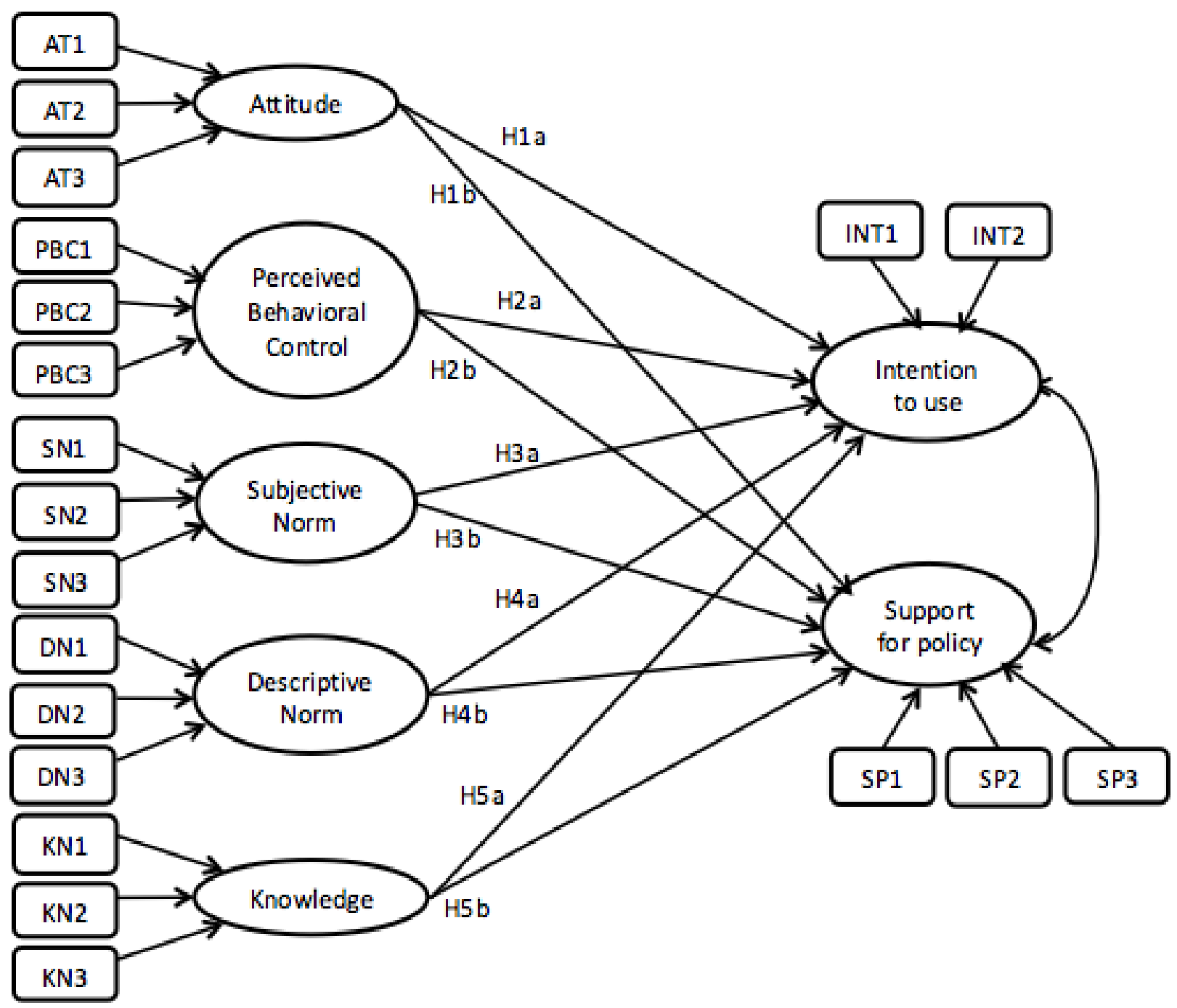

Fig. 1: The proposed model 


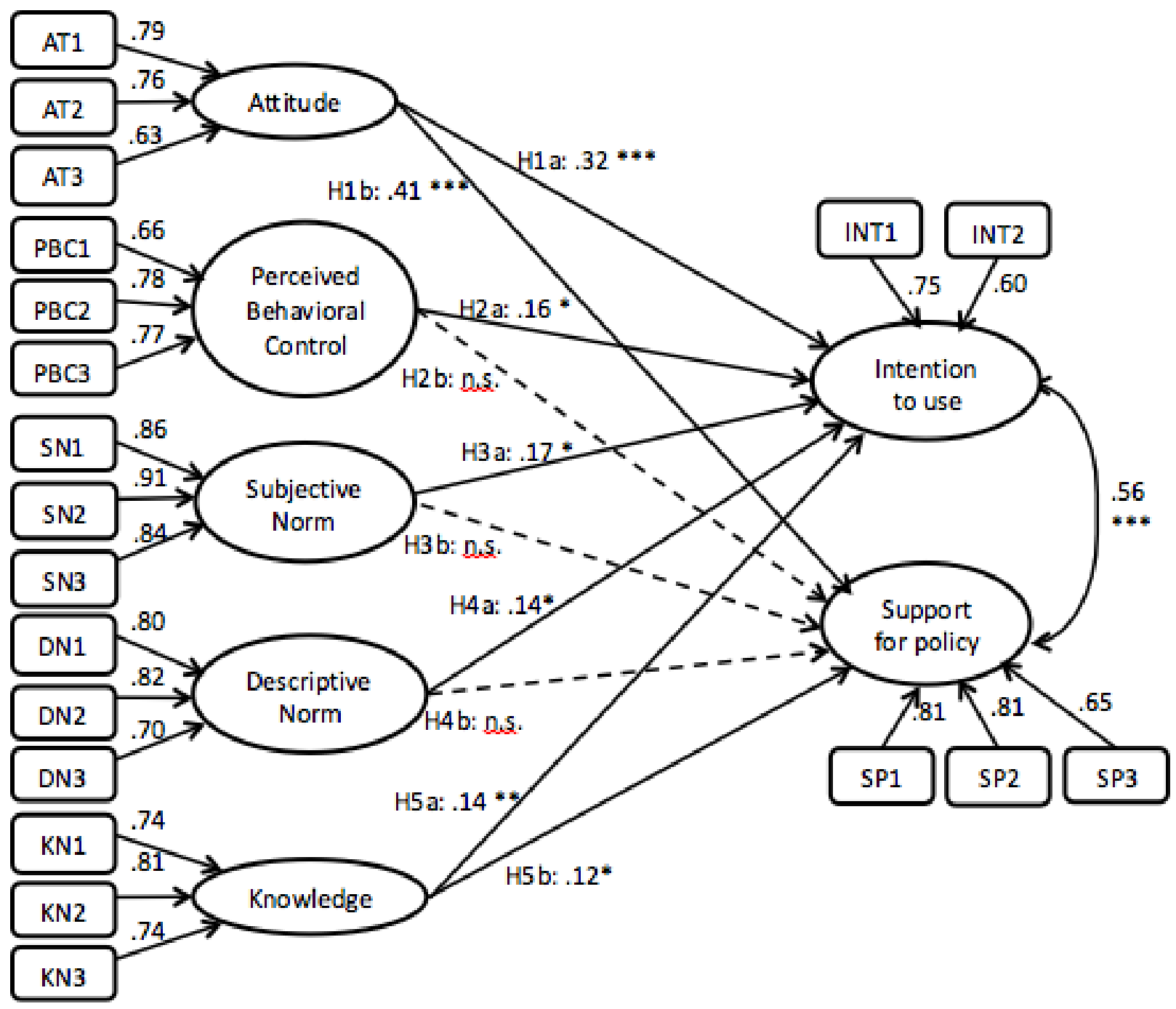

$* * * p<.001, * * p<.01, * p<.05$, and $n . s$. means not significant

Fig. 2: The structural model 
Table 1: means and standard deviations of the items of major variables

\begin{tabular}{|c|c|c|c|}
\hline \multicolumn{2}{|c|}{ Variables and Items: } & \multirow[t]{2}{*}{ Mean } & \multirow[t]{2}{*}{$\mathrm{SD}$} \\
\hline & Attitudes toward environmental protection & & \\
\hline AT1 & $\begin{array}{l}\text { Manufacturers should reduce the manufacturing of dispensable } \\
\text { products. }\end{array}$ & 4.23 & 0.84 \\
\hline AT2 & $\begin{array}{l}\text { Abusive use of environmental resources will harm the wellbeing of } \\
\text { our next generation. }\end{array}$ & 4.47 & 0.71 \\
\hline \multirow[t]{2}{*}{ AT3 } & China needs more strict environmental laws. & 4.25 & 0.83 \\
\hline & Perceived behavioral control (PBC) on energy conservation & & \\
\hline PBC1 & I have control over how I consume or save energy. & 3.86 & 0.90 \\
\hline $\mathrm{PBC} 2$ & $\begin{array}{l}\text { If most of your classmates do not try to save energy, would you still } \\
\text { take the initiative to save energy? }\end{array}$ & 3.99 & 0.80 \\
\hline \multirow[t]{2}{*}{ PBC3 } & $\begin{array}{l}\text { If there was no sufficient support from your friends for saving } \\
\text { energy, would you still take the initiative to save energy? }\end{array}$ & 4.00 & 0.82 \\
\hline & Subjective norms of sustainable behaviors & & \\
\hline SN1 & Most of my close friends think that I should save water. & 4.07 & 0.89 \\
\hline SN2 & Most of my close friends think that I should to recycle. & 4.05 & 0.79 \\
\hline \multirow[t]{2}{*}{ SN3 } & Most of my close friends think that I should save electricity. & 4.13 & 0.75 \\
\hline & Descriptive norms of sustainable behaviors & & \\
\hline DN1 & Most of my close friends save electricity. & 3.76 & 0.90 \\
\hline DN2 & Most of my close friends save water. & 3.87 & 0.86 \\
\hline \multirow[t]{2}{*}{ DN3 } & $\begin{array}{l}\text { Most of my close friends buy products made from recycled } \\
\text { materials. }\end{array}$ & 3.66 & 0.92 \\
\hline & Perceived knowledge on renewable energy & & \\
\hline KN1 & I am familiar with the knowledge of solar power energy. & 3.84 & 0.85 \\
\hline $\mathrm{KN} 2$ & I am familiar the knowledge of wind power energy. & 3.51 & 0.89 \\
\hline \multirow[t]{2}{*}{ KN3 } & I am familiar with the knowledge of hydropower energy. & 3.80 & 0.84 \\
\hline & Intention to use renewable energy technology & & \\
\hline INT1 & I will use a solar water heater at home in the future. & 4.27 & 0.89 \\
\hline \multirow[t]{2}{*}{ INT2 } & I will drive an alternative fuel vehicle in the future. & 4.08 & 0.83 \\
\hline & Support for new energy policy & & \\
\hline SP1 & Chinese government should develop more solar energy technology. & 4.36 & 0.78 \\
\hline SP2 & Chinese government should develop more wind energy technology. & 4.31 & 0.80 \\
\hline SP3 & $\begin{array}{l}\text { Chinese government should encourage more research on renewable } \\
\text { energy, including hydrogen or clean coal energy. }\end{array}$ & 4.29 & 0.78 \\
\hline
\end{tabular}


Table 2: Measures of the reliability and validity of the measurement model

\begin{tabular}{llllllll}
\hline & Intention & Support & Attitude & PBC & $\begin{array}{l}\text { Subjective } \\
\text { norm }\end{array}$ & $\begin{array}{l}\text { Descriptive } \\
\text { norm }\end{array}$ & Knowledge \\
\hline Intention & - & 0.73 & 0.6 & 0.56 & 0.56 & 0.49 & 0.40 \\
Support & 0.73 & - & 0.54 & 0.43 & 0.42 & 0.36 & 0.32 \\
Attitude & 0.6 & 0.54 & - & 0.59 & 0.58 & 0.36 & 0.27 \\
PBC & 0.56 & 0.43 & 0.59 & - & 0.48 & 0.48 & 0.41 \\
Subjective Norm & 0.56 & 0.42 & 0.58 & 0.48 & - & 0.61 & 0.33 \\
Descriptive Norm & 0.49 & 0.36 & 0.36 & 0.48 & 0.60 & - & 0.39 \\
Knowledge & 0.40 & 0.32 & 0.27 & 0.41 & 0.33 & 0.39 & - \\
CR & 0.63 & 0.80 & 0.77 & 0.78 & 0.91 & 0.82 & 0.81 \\
AVE & 0.46 & 0.58 & 0.53 & 0.54 & 0.76 & 0.60 & 0.58 \\
MSV & 0.53 & 0.53 & 0.36 & 0.35 & 0.36 & 0.36 & 0.36 \\
ASV & 0.32 & 0.24 & 0.26 & 0.25 & 0.26 & 0.21 & 0.13 \\
\hline
\end{tabular}

